С. О. Шаповалов, М. М. Долгая

Інститут тваринництва УААН України

\title{
ВІТАМІННЕ ЗАБЕЗПЕЧЕННЯ ОРГАНІЗМУ ПОРОСЯТ ЗА УМОВ УВЕДЕННЯ МІКРОЕЛЕМЕНТНОЇ КОМПОЗИЦЇ̈ СУПОРОСНИМ СВИНОМАТКАМ ТА ПОРОСЯТАМ У РАННЬОМУ ПОСТНАТАЛЬНОМУ ОНТОГЕНЕЗІ
}

Оцінено вплив мікроелементної композиції «Біотам» на вміст вітамінів $A, E, C, B_{2}$ у крові, печінці та м'язах поросят у ранньому постнатальному онтогенезі. Показано достовірне підвищення їх концентрації у дослідній групі тварин, які отримували препарат «Біотам».

С. О. Шаповалов, М. Н. Долгая

Институт жсивотноводства НААН Украинь

\section{ВИТАМИННОЕ ОБЕСПЕЧЕНИЕ ОРГАНИЗМА ПОРОСЯТ ПРИ ВВЕДЕНИИ МИКРОЭЛЕМЕНТНОЙ КОМПОЗИЦИИ СУПОРОСНЫМ СВИНОМАТКАМ И ПОРОСЯТАМ В РАННЕМ ПОСТНАТАЛЬНОМ ОНТОГЕНЕЗЕ}

Оценено влияние микроэлементной композиции «Биотам» на содержание витаминов $A, E, C$, $B_{2}$ в крови, печени и мышцах поросят в раннем постнатальном онтогенезе. Показано достоверное повышение их концентрации в опытной группе животных при использовании препарата «Биотам».

S. O. Shapovalov, M. N. Dolgaya

Institute of Animal Husbandry NAAS of Ukraine

\section{VITAMINS SUPPLY OF PIGLETS UNDER INTRODUCTION OF MICROELEMENTS COMPOSITION INTO SOWS AND PIGLETS IN EARLY POSTNATAL ONTOGENESIS}

Data on the influence of «Biotam» microelements composition on the level of vitamins $A, E, B_{2}$ in blood, liver and muscles of piglets in early postnatal ontogenesis are presented. Significant increase of its concentrations in the animals of the experimental group is shown.

\section{Вступ}

Найважливіші умови стабілізації виробництва тваринницької продукції, поліпшення іiі біологічної цінності та якості - максимальне збереження новонародженого молодняку та забезпечення високої життєздатності тварин. На сучасному етапі розвитку технологій у тваринництві відбувається активне впровадження нових лікарських засобів, які відповідають високим фармакологічним вимогам [3; 5; 8]. До такої універсальної субстанції належить мікроелементний комплекс «Біотам» - композиція поліяденрних комплексів есенційних мікроелементів. Природа і мольне співвідношення 
мікроелементів, які входять до композиції, відповідають їх складу у металумісних ферментах. Поєднання цих комплексів максимальне за своєю спрямованістю і може сприяти стимуляції та стабілізації обмінних процесів у організмі в цілому. Окреме важливе завдання - максимальне збереження депо жиророзчинних вітамінів у печінці поросят, які надійшли від свиноматки на етапі ембріогенезу, до повної нормалізації вітамінно-обмінних процесів $[2 ; 4 ; 6]$.

Показано, що у промислових умовах поросята на ранньому етапі розвитку не можуть отримати фізіологічно необхідну дозу жиророзчинних вітамінів навіть із використанням ряду вітамінумісних препаратів [7]. Існують суперечливі погляди щодо можливостей організму поросят у ранньому онтогенезі трансформувати отримані вітаміни [5; 6]. Є також дані, що в організмі підсисних поросят трансформація та перетворення вітамінів із провітамінів майже не відбувається. Тому вітамінна забезпеченість новонародженого молодняку можлива, перш за все, завдяки використанню молозива $[1 ; 2 ; 7]$. За даними інших дослідників, інтенсивність трансформації вітамінів в організмі поросят до 40-добового віку дуже повільна [2].

Специфічний критерій забезпеченості організму вітамінами $A, E, C$ - визначення ï вмісту у плазмі крові та печінці. Інші автори наполягають на дослідженні вітамінів саме у печінці, оскільки вона здатна депонувати вітаміни $A$ та $E$ і визначення їх саме у цьому органі може бути додатковим критерієм забезпеченості організму цими вітамінами $[1,2]$.

3 огляду на вищевикладене завдання наших досліджень - визначити можливість регуляції та накопичення цих вітамінів завдяки уведенню композиції поліядерних комплексів есенційних мікроелементів поросятам у ранньому постнатальному онтогенезі.

\section{Матеріал і методи досліджень}

Дослідження проведене у ДГ «Гонтарівка» Вовчанського району Харківської області на 12 супоросних свиноматках, поділених на дві групи (дослідну та контрольну) за принципом пар-аналогів по шість тварин у кожній. Біохімічні дослідження крові проводили на базі Випробувального центру Екологічного моніторингу та дослідження якості продукції тваринного походження Інституту тваринництва УААН. Свиноматкам дослідної групи за три тижні до опоросу давали мікроелементну композицію «Біотам» у дозі 20 мг/кг маси тіла щоденно до опоросу, тварини перебували на стандартному раціоні для цієї фізіологічної групи. Після опоросу з групи, що отримувала «Біотам», сформовано дві групи поросят за принципом пар-аналогів, та за цим же принципом групу контрольних тварин. Таким чином сформовано три групи поросят. На 7 та 14-ту добу проводили забір крові у поросят безпосередньо із серця. На 35-ту добу тварин було забито. У крові на 7, 14 та 35-ту добу та на 35 добу у печінці визначали концентрацію вітамінів $A, E$ та $C$.

Визначення вітаміну $A$ та каротиноїдів проводили за методом П. Ф. Сурая та I. А. Іонова. Визначення вітаміну $E$ проводили за методом Еммері - Енгеля у модифікації П. Ф. Сурая. Визначення вітаміну $C$ проводили за модифікованим методом В. А. Девятніна. Вміст аскорбінової кислоти (АК) визначають за різницею між сумою АК + ДАК і ДАК [1]. Препарат «Біотам», який уводили свиноматкам у вигляді сухої форми, містить композицію мікроелементів, у якій містяться індивідуальні комплекси металів $\mathrm{Zn}^{2+}, \mathrm{Cu}^{2+}, \mathrm{Co}^{2+}, \mathrm{Cr}^{3+}, \mathrm{Fe}^{3+}, \mathrm{Mn}^{2+}$ з $\mathrm{N}$-2,3-диметилфенілантраніловою (мефенаміновою) кислотою. Вміст мікроелементів у 1 грамі: $\mathrm{Zn}^{2+}-17$ мг, $\mathrm{Cu}^{2+}-3,7$ мг, $\mathrm{Co}^{2+}$ 0,35 мг, $\mathrm{Cr}^{3+}-0,3 \mathrm{мг}, \mathrm{Fe}^{3+}-14,5$ мг, $\mathrm{Mn}^{2+}-4$ мг, $\mathrm{N}-2,3$-диметилфенілантранілової кислоти - 412 мг, глюконат кальцію - 180 мг, і крохмаль, цукор, аеросил до 1 г. Препарат 
«Біотам», який уводили поросятам першої групи у вигляді гелю, містив мікроелементів у $50 \mathrm{~cm}^{3}: \mathrm{Zn}^{2+}-17 \mathrm{мг}, \mathrm{Cu}^{2+}-3,7 \mathrm{мг}, \mathrm{Co}^{2+}-0,35 \mathrm{мг}, \mathrm{Cr}^{3+}-0,3 \mathrm{мг}, \mathrm{Fe}^{3+}-14,5 \mathrm{мг}, \mathrm{Mn}^{2+}-$ 4 мг, $N$-2,3-диметилфенілантранілової кислоти -412 мг. Таким чином дослідній групі поросят додатково уведено протягом експерименту $7 \mathrm{~cm}^{3}$ препарату на голову (табл. 1).

\section{Схема дослідження}

Таблиия 1

\begin{tabular}{|c|c|c|c|c|}
\hline Групи & Тварини & Групи & Тварини & Доза препарату \\
\hline \multirow{2}{*}{ Дослід } & $\begin{array}{c}\text { Супоросні свиноматки } \\
\text { за 3 тижні до опоросу, }\end{array}$ & 1 & поросята $(n=6)$ & $\begin{array}{c}32 \text { по 8-му добу, щодня } \\
1 \mathrm{~cm}^{3} / \text { гол./добу per оs у вигляді гелю }\end{array}$ \\
\cline { 3 - 5 } Контроль & $\begin{array}{c}\text { Супоросні свиноматки } \\
\text { Ка 3 тижні до опоросу, ОР }\end{array}$ & К & поросята $(n=15)$ & - \\
\hline
\end{tabular}

\section{Результати досліджень}

У дослідних групах спостерігається достовірне підвищення концентрації вітаміну $A$ у сироватці порівняно 3 контролем в другій групі на 14-ту та 35 -ту добу на 7,8 та 18,8 \% відповідно (табл. 2). У той же час відмічене збільшення вмісту ретинолу в контрольній групі з 7-ї до 35-ї доби на 0,22 мкг/ $\mathrm{cm}^{3}$, а у другій дослідній групі - на 0,36 мкг $/ \mathrm{cm}^{3}$. Рівень вітаміну $E$ у сироватці крові поросят другої дослідної групи достовірно вищий за контроль на $14-$ у добу в 1,2 , а на 35 -у добу в 1,5 раза. У другій дослідній групі спостерігається тенденція до підвищення концентрації $\alpha$-токоферолу в сироватці крові. При дослідженні зразків сироватки крові встановлено, що концентрація аскорбінової кислоти у поросят контрольної та дослідної групи не відрізняється вірогідно, крім другої дослідної групи, на 35-ту добу, де ця різниця вища на $10 \%$ відносно контролю $(p<0,05)$. У цілому спостерігається підвищення концентрації вітаміну $C$ з 7-ї по 35-ту добу як у дослідних, так і контрольній групах на 27-35 \%.

Вміст вітамінів $A, E, C$ (мкг/см³) у плазмі крові поросят

Таблиия 2

\begin{tabular}{|c|c|c|c|}
\hline \multirow{2}{*}{$\begin{array}{c}\text { Термін } \\
\text { відбору проби }\end{array}$} & контроль & Групи тварин \\
\hline \multicolumn{3}{|c|}{ вітамін $E$} \\
\hline 7-ма доба & $1,56 \pm 0,19$ & $1,60 \pm 0,07$ & дослід 2 \\
\hline 14-та доба & $2,53 \pm 0,03$ & $2,69 \pm 0,08$ & $1,81 \pm 0,11$ \\
\hline 35-та доба & $3,32 \pm 0,17$ & $3,85 \pm 0,09$ & $4,05 \pm 0,04^{*}$ \\
\hline \multicolumn{4}{|c|}{ вітамін $A$} \\
\hline 7-ма доба & $0,89 \pm 0,03$ & $1,03 \pm 0,04$ & $1,01 \pm 0,04$ \\
\hline 14-та доба & $1,05 \pm 0,02$ & $1,10 \pm 0,07$ & $1,14 \pm 0,03^{* *}$ \\
\hline 35-та доба & $1,11 \pm 0,08$ & $1,12 \pm 0,07$ & $1,37 \pm 0,04^{* * *}$ \\
\hline \multicolumn{4}{|c|}{ вітамін C } \\
\hline 7-ма доба & $1,21 \pm 0,09$ & $1,19 \pm 0,07$ & $1,28 \pm 0,08$ \\
\hline 14-та доба & $1,45 \pm 0,04$ & $1,32 \pm 0,16$ & $1,44 \pm 0,03$ \\
\hline 35-та доба & $1,77 \pm 0,05$ & $1,65 \pm 0,07$ & $1,98 \pm 0,01 *$ \\
\hline
\end{tabular}

Примітки: ${ }^{*}-p<0,05,{ }^{* *}-p<0,01$ порівняно з контролем.

Дослідження функціонального стану біохімічних реакцій у клітинах печінки досить інформативне у зв'язку з роллю печінки в обміні речовин. У результаті проведених досліджень (табл. 3) встановлено, що в печінці дослідної групи поросят 35добового віку збільшився рівень усіх досліджених вітамінів. Концентрація вітаміну $A$ достовірно збільшилась у другій дослідній групі на $17 \%$, вітаміну $E$ - на $32 \%$, кароти- 
ноїдів - на $38 \%$, вітаміну $B_{2}-$ на $2 \%$. Що стосується рівня вітаміну $C$, то було показано, в дослідній групі 1 він був вищим на $6,9 \%$, а в дослідній групі 2 - на 10,1\%. Проте рівень відновленої форми аскорбінової кислоти був також на $6 \%$ вищим у дослідній групі 1, а в дослідній групі 2 він був вищим на 13,0\%. Слід зазначити, що у дослідній групі 2 рівень дегідроаскорбінової кислоти був меншим на 3,0 \%. Таким чином, у дослідній групі 2 у печінці переважає відновлена форма вітаміну $C$.

Вміст вітамінів $A, E, B_{2}$ і каротиноїдів у печінці поросят

Таблиия 3

\begin{tabular}{|c|c|c|c|}
\hline Група & Контрольна & Дослідна 1 & Дослідна 2 \\
\hline Вітамін $A$, мкг $/ \Gamma$ & $33,2 \pm 0,3$ & $34,3 \pm 1,4$ & $40,4 \pm 1,1^{*}$ \\
\hline Вітамін $E$, мкг/Г & $29,8 \pm 2,2$ & $31,2 \pm 1,4$ & $44,2 \pm 2,5^{*}$ \\
\hline Каротиноїди, мкг/г & $0,16 \pm 0,01$ & $0,18 \pm 0,01$ & $0,26 \pm 0,02 * *$ \\
\hline Вітамін $B_{2}$, мкг/г & $0,139 \pm 0,002$ & $0,135 \pm 0,004$ & $0,142 \pm 0,001$ \\
\hline Вітамін $C(\mathrm{AK}+$ ДАК $)$, мкг $/ \Gamma$ & $202,3 \pm 14,2$ & $217,3 \pm 1,2$ & $225,1 \pm 3,3 * *$ \\
\hline Аскорбінова кислота (АК), мкг/г & $165,4 \pm 11,1$ & $176,2 \pm 10,1$ & $190,4 \pm 14,3$ \\
\hline Дегідроаскорбінова кислота (ДАК), мкг/г & $36,9 \pm 0,1$ & $41,0 \pm 2,1$ & $34,7 \pm 0,2$ \\
\hline Вітамін $A$, мг/орган & $6,1 \pm 1,1$ & $6,7 \pm 1,1$ & $8,7 \pm 1,1^{*}$ \\
\hline Вітамін $E$, мг/орган & $5,5 \pm 1,5$ & $6,1 \pm 1,1$ & $9,5 \pm 2,1 * *$ \\
\hline Каротиноїди, мкг/орган & $29,6 \pm 11,3$ & $34,9 \pm 12,4$ & $55,9 \pm 5,7 * *$ \\
\hline Вітамін $B_{2}$, мкг/орган & $25,5 \pm 1,1$ & $26,1 \pm 1,1$ & $30,4 \pm 2,4^{*}$ \\
\hline Вітамін $C(\mathrm{AK}+$ ДАК $)$, мг/орган & $37,4 \pm 2,2$ & $42,2 \pm 2,5$ & $48,4 \pm 2,4^{* *}$ \\
\hline Аскорбінова кислота, мг/орган & $30,6 \pm 1,3$ & $34,2 \pm 2,5$ & $40,9 \pm 4,6^{*}$ \\
\hline Дегідроаскорбінова кислота, мг/орган & $6,8 \pm 0,3$ & $7,9 \pm 0,9$ & $7,5 \pm 0,7^{*}$ \\
\hline
\end{tabular}

Примітки: див. табл. 2.

За умов порівняння концентрації вітамінів у цілому органі показано, що в дослідних групах 1 та 2 уміст вітаміну $A$ вищий на 7,6 та 29,0\% відповідно, вміст вітаміну $E$ - на 9,1 та $41,9 \%$, каротиноїдів - на 15,2 та $47,0 \%$, вітаміну $B_{2}$ - на 2,1 та $16,0 \%$, вітаміну C - на 11,2 та 22,6 \%, аскорбінової кислоти - на 10,5 та 25,3 \%, дегідроаскорбінової кислоти - вищий на 14,3 та 8,6 \% відповідно.

При застосуванні мікроелементної композиції на 35-ту добу дослідження встановлено (табл. 4) достовірний $(p<0,05)$ підвищений рівень вмісту вітаміну $A$ у м'язах у дослідній групі 1 на 46,0\%, у дослідній групі 2 - на 53,0 \%, вищу концентрацію вітаміну $E$ (на $18,0 \%, p<0,01)$ у дослідній групі 2.

Вміст вітамінів $\boldsymbol{A}$ та $\boldsymbol{E}$ (мкг/г) у м'язовій тканині поросят,

Таблиия 4

\begin{tabular}{|l|c|c|c|}
\hline \multicolumn{1}{|c|}{ Група } & Контрольна & Дослідна 1 & Дослідна 2 \\
\hline Вітамін $A$ & $1,29 \pm 0,07$ & $2,39 \pm 0,12^{*}$ & $2,77 \pm 0,17^{* *}$ \\
\hline Вітамін $E$ & $1,44 \pm 0,10$ & $1,49 \pm 0,12$ & $1,77 \pm 0,12^{* *}$ \\
\hline
\end{tabular}

Примітки: див. табл. 2.

При розгляді принципової схеми рециклізації антиоксидантів, запропонованої L. Packer [10], можна припустити, що введення композиції мікроелементів запобігає втраті вітамінів у процесі їх рециклізації за рахунок активізації ферментативної ланки антиоксидантної системи: глютатіонзалежним ферментам (СОД та каталазі), оскільки іони металів, що містяться у досліджуваній композиції, входять до складу цих ферментних систем, виконуючи в активних центрах оксидоредуктаз каталітичну роль, i безпосередньо беруть участь у здійсненні більшості окисно-відновних реакцій, стримуючи розвиток вільнорадикального окиснення. 


\section{Висновки}

Уведений комплекс мікроелементів виявляє позитивний вплив на накопичення вітамінів $A$ та $E$, каротиноїдів у печінці та м'язах поросят, що створює необхідний запас для ефективного отримання метаболічних енергосубстратів і підвищення антиоксидантного захисту та резистентності організму поросят у ранньому постнатальному онтогенезі.

\section{Бібліографічні посилання}

1. Витамины в питании животных. Метаболизм и потребность / А. Р. Вальдман, П. Ф. Сурай, И. А. Ионов, Н. И. Сахацкий. - Харьков : Оригинал, 1993. - 423 с.

2. Витамины в кормлении сельскохозяйственных животных / О. Е. Привало, С. М. Паенок, С. М. Гусак и др. - К. : Урожай, 1983. - 160 с.

3. Горбачев В. В. Витамины, микро- и макроэлементы / В. В. Горбачев, В. Н. Горбачев. - Минск : Интерпречсервис, 2002. - 300 с.

4. Двинская Л. М. Физиолого-биохимические основы витаминного питания сельскохозяйственных животных // Научные основы витаминного питания сельскохозяйственных животных. Тез. докл. II Всесоюзн. симпоз. - Рига, 1987. - С. 78-80.

5. Калетина Н. И. Биокомплексы микроелементов - регуляторы металло-лигандного гомеостаза / Н. И. Калетина, Е. В. Арзамасцев // Микроэлементы в медицине. - 2002. - № 3 (1). - С. 8-14.

6. Крюков В. С. Нормирование жирорастворимых витаминов / В. С. Крюков, П. Ф. Сурай, И. А. Ионов // Птицеводство. - 1991. - № 9. - С. 11-17.

7. Куртяк Б. М. Жиророзчинні вітаміни у ветеринарній медицині і тваринництві / Б. М. Куртяк, В. Г. Янович. - Львів, 2004. - 425 с.

8. Оберлис Д. Новый подход к проблеме дефицита микроэлементов // Микроэлементы в медицине. - 2002. - № 3 (1). - С. 2-7.

9. Сурай П. Ф. Биохимические методы контроля метаболизма в органах и тканях птиц и их витаминной обеспеченности (методические рекомендации) / П. Ф. Сурай, И. А. Ионов. - Харьков, 1990. - 138 с.

10. Packer L. Interactions among antioxidants in health and disease: Vitamin $E$ and its redox cycle // Proc. Soc. Exp. Biol. and Med. - 1992. - Vol. 20. - P. 271-276.

Надійшла до редколегії 14.12.2010 